\title{
Public Goods and Ethnic Divisions
}

\section{Citation}

Alesina, Alberto, Reza Baqir, and William Easterly. 1999. Public goods and ethnic divisions. Quarterly Journal of Economics 114(4): 1243-1284.

\section{Published Version}

http://dx.doi.org/10.1162/003355399556269

\section{Permanent link}

http://nrs.harvard.edu/urn-3:HUL.InstRepos:4551797

\section{Terms of Use}

This article was downloaded from Harvard University's DASH repository, and is made available under the terms and conditions applicable to Other Posted Material, as set forth at http:// nrs.harvard.edu/urn-3:HUL.InstRepos:dash.current.terms-of-use\#LAA

\section{Share Your Story}

The Harvard community has made this article openly available.

Please share how this access benefits you. Submit a story.

Accessibility 


\title{
PUBLIC GOODS AND ETHNIC DIVISIONS*
}

\author{
ALBERTO Alesina \\ REZA BAQIR \\ WILLIAM EASTERLY
}

We present a model that links heterogeneity of preferences across ethnic groups in a city to the amount and type of public goods the city supplies. We test the implications of the model with three related data sets: U.S. cities, U.S. metropolitan areas, and U.S. urban counties. Results show that the shares of spending on productive public goods-education, roads, sewers and trash pickup-in U. S. cities (metro areas/urban counties) are inversely related to the city's (metro area's/county's) ethnic fragmentation, even after controlling for other socioeconomic and demographic determinants. We conclude that ethnic conflict is an important determinant of local public finances.

\begin{abstract}
"Many white Americans have turned against a strategy that emphasizes programs they perceive as benefiting only racial minorities. ... Public services became identified mainly with blacks, private services mainly with whites ... white taxpayers saw themselves as being forced, through taxes, to pay for medical and legal services that many of them could not afford ..." from Wilson [1996, pp. 193, 202].
\end{abstract}

\section{INTRODUCTION}

When individuals have different preferences, they want to pull fewer resources together for public projects. This paper argues that certain public goods-such as education, roads, sewers - supplied by U. S. cities are inversely related to ethnic fragmentation in those cities. In cities where ethnic groups are polarized, and where politicians have ethnic constituencies, the share of spending that goes to public goods is low. Representatives

* We thank Roland Bénabou, Anne Case, Allan Drazen, Edward Glaeser, Karin Kimbrough, Ross Levine, Norman Loayza, Giovanni Peri, Lant Pritchett, Fabio Schiantarelli, Andrei Shleifer, two anonymous referees, and seminar participants at Duke University, Princeton University, Rutgers University, Boston College, Harvard University, two NBER conferences, the National Tax Association, and the World Bank for useful comments. We are grateful to Giuseppe Iarossi for excellent research assistance. This research is supported by an NSF grant through the National Bureau of Economic Research; we thank both organizations for their support. Alesina is also grateful to the Center for International Affairs at Harvard University for financial support. Views expressed here are not to be taken as those of the World Bank or its member countries.

1999 by the President and Fellows of Harvard College and the Massachusetts Institute of Technology.

The Quarterly Journal of Economics, November 1999 
of interest groups with an ethnic base are likely to value only the benefits of public goods that accrue to their groups, and discount the benefits for other groups. This can happen for two nonmutually exclusive reasons. One is that different ethnic groups have different preferences over which type of public goods to produce with tax revenues. The second is that each ethnic group's utility level for a given public good is reduced if other groups also use it. Undervaluing public goods provision, political actors choose to divert more public resources to private patronage.

The finding of this paper is not that when a particular ethnic group becomes a majority in a particular locality it lowers the provision of public goods. In fact, it turns out that our results are mainly driven by how white majority cities react to varying minority group sizes. The finding is that voters choose lower public goods when a significant fraction of tax revenues collected on one ethnic group are used to provide public goods shared with other ethnic groups.

Here is an anecdote. Prince George's (PG) County, a Maryland county next to Washington, DC, used to have a large white majority. After the influx of a large black middle class made the county much more diverse (although whites were still in the majority), PG voters passed a law called TRIM in 1978. TRIM puts a legal ceiling on the property tax rate, a binding constraint on the main source of revenue for school financing. Observers conventionally cite TRIM as one reason for poor schools in PG County. The county next door to PG County is Montgomery County, also a DC suburb. Montgomery is regionally (and even nationally) famous for the quality of its public schools. Montgomery has a much larger white majority and so is less ethnically diverse than PG. Montgomery voters have decisively rejected tax limitation laws on several occasions. While Montgomery residents are 47 percent richer than PG residents, on average, the disparity in public schools appears to be greater than can be explained by this income difference. For example, Montgomery County collects 2.4 times more local education revenue per pupil than does PG County.

It is hardly a new insight to argue that urban problems in America have something to do with ethnic conflict. Conventional wisdom particularly points to racial tension in public education. However, we go well beyond this point and specifically document how ethnic fragmentation influences local public goods, as re- 
flected in the composition of spending, the aggregate total of spending, and the budget balance. ${ }^{1}$

The paper is organized as follows. Section I reviews some of the most relevant literature for our question. Section II develops a simple model that illustrates the relationship between polarization of preferences and public goods provision. Section III presents empirical evidence drawn from cities, metropolitan areas, and urban counties. Section IV discusses many issues of sensitivity analysis. The last section concludes and indicates possibilities for further research.

\section{Previous Literature}

Our paper crosses the boundaries of several branches of the literature. First, we have a small (but rapidly growing) literature that seeks to explain the formation of borders of political jurisdictions as a function of diversity of individual preferences and economies of scale in the financing of public goods. In particular, the model of the present paper is related to the one by Alesina and Spolaore [1997]. On the empirical side Easterly and Levine [1997] report a strong negative correlation across countries between ethnic diversity (as measured by language) and indicators of public goods, such as numbers of telephones, percentage of roads paved, efficiency of the electricity network, and years of schooling. They conclude that ethnic diversity has something to do with Africa's poor economic growth. ${ }^{2}$

Second, a burgeoning literature on income inequality describes how neighborhood segregation by class (which has a strong ethnic dimension, although this is not emphasized by this literature) can play havoc with the public provision of education. Durlauf [1996] and Bénabou [1996a] develop models that show how city-suburb polarization is inefficient for human capital accumulation with local school financing. However, attempts to

1. The problem of ethnic polarization is not limited to blacks versus whites. As Wilson [1996] points out, "antagonism toward inner city blacks is frequently expressed in the Latino neighborhoods that border the new poverty areas." The same author also emphasizes the Korean versus inner city blacks tensions which exploded in incidents in New York and Los Angeles.

2. They also find that financial repression is more severe and black market premiums are higher in ethnically diverse countries. (As an aside, popular discussion often compares troubled American cities with Third World countries. The American international aid agency, USAID, even gave advice to Baltimore about one kind of public goods supply - childhood immunization). 
equalize spending in a polarized society only weaken support for spending on schooling. ${ }^{3}$

Several recent empirical papers on topics related to ours that feature U. S. city data are those by Glaeser, Scheinkman, and Shleifer [1995], Cutler and Glaeser [1995], Poterba [1996], Luttmer [1997], and Goldin and Katz [1998]. Glaeser, Scheinkman, and Shleifer find that one measure of city developmentpopulation growth-is worse in cities with a higher percentage nonwhite population (although this effect weakens with unemployment and schooling controls). Cutler and Glaeser find that blacks have worse outcomes on education, income, and other social dimensions in more segregated metropolitan areas. Perhaps poor public goods outcomes contribute to explaining these adverse outcomes in racially polarized cities. Poterba finds that a larger fraction of elderly in a jurisdiction leads to lower public spending on education. Interestingly, and in accordance with the argument of this paper, he also finds that "this reduction is particularly large when the elderly residents and the school age population are from different racial groups." Cutler, Elmendorf, and Zeckhauser [1993] find support for their hypothesis that people have "discriminatory community preferences," where they only "care about the welfare of others within their [ethnic] community" [P. 180]. Likewise, Luttmer shows empirically that "individuals increase their support for welfare spending if a larger fraction of welfare recipients in their area belongs to their racial group" [p. 1]. Goldin and Katz study the period (early this century) in which universal and publicly funded education became predominant in the United States. They find that "more ethnic and religious homogeneity fostered high school expansion from 1910 to 1930" [p. 1].

Third, a large local public finance literature inspired by Tiebout's model bears on our topic, and focuses on the problem that heterogeneity of citizens creates for public good provision [Rubinfield 1987]. Tiebout's [1958] resolution of the heterogeneity problem was that people can sort themselves into communities that provide the public goods they want. However, subsequent literature has pointed out numerous problems with Tiebout sorting, such as the restricted number of communities, the multidimensional nature of public goods, limitations to mobility,

3. Borjas [1995] finds that there are "ethnic capital" effects even after controlling for neighborhood effects. This may create incentives for segregation along ethnic as well as class lines, although Borjas does not explore this particular implication. 
and economies of scale in public goods provision [Rubinfeld 1987; Atkinson and Stiglitz 1980]. The social externalities raised by the inequality literature, as discussed above, also complicate the predictions of the Tiebout model. Finally, there are legal constraints to extreme segregation by ethnic group, even if these constraints are only very partially effective. ${ }^{4}$ Thus, despite the possibility of sorting, heterogeneous preferences within a community will not disappear in practice. This is all we need for our model.

In addition, the empirical local public finance literature has one finding that may be relevant to our study. Many studies of individual preferences find that blacks are more supportive of spending on public education than whites. ${ }^{5}$ This is interesting because it suggests that any association of increased ethnic diversity (which often means more blacks in the U. S. data) with lower public education is not due to the fact that blacks themselves have a lower demand for public education.

Fourth, the sociological literature has also pointed to ethnic divisions as a problem for public goods provision. Lieberman [1993] writes that: "Ethnic groups must reach an accommodation on various issues. As the accommodations become more distasteful to one or more groups, the disaffected parties become more supportive of alternatives to public education" [p. 171]. The implication of this fact is a vicious circle, emphasized most vocally by Wilson $[1987,1996]$. Poor minorities in highly segregated cities need good public schools to improve their skills, but public schools provision is low because of ethnic conflict. The relative skill levels of minorities in ghettos does not improve, and their poverty level increases, making problems of central cities' unemployment and decay even worse-and ethnic conflicts even more acute.

\section{THEORY}

We first present the basic model and then discuss several extensions.

\section{A. The Basic Model}

Consider a political jurisdiction in which the population size is normalized at 1 , with no loss of generality. There is no mobility

4. Examples are fair housing laws, housing discrimination lawsuits, and recent court battles over locating subsidized public housing (mainly occupied by blacks) in wealthy white communities.

5. See Rubinfeld, Shapiro, and Roberts [1987] for references and a summary. 
in or out of the jurisdiction. ${ }^{6}$ The members of the jurisdiction have to decide, by majority rule, on a public good, both on its size and type. Public goods can be of different types, and different individuals have different preferences over them. The generic individual $i$ 's utility function is given by

$$
\begin{gathered}
u_{i}=g^{a}\left(1-l_{i}\right)+c \\
0<\alpha<1,
\end{gathered}
$$

where $g$ is the public good, which can be located anywhere on an ideological line capturing different individuals' preferences; $l_{i}$ is the preference distance between individual $i$ 's most preferred type of public good and the actual public good; $c$ is private consumption. Income is exogenous and equal for everybody. ${ }^{7}$ Private consumption is equal to disposable income:

$$
c=y-t,
$$

where $y$ is the exogenous pretax income and $t$ is the lump-sum tax which, by assumption, is identical for everyone. This is natural, since everybody has the same pretax income, and a standard assumption in public finance is that taxes cannot be a function of individual preferences. ${ }^{8}$ Note that since the population size is normalized at 1 , per capita and and aggregate variables are identical, so, for instance, $g$ represents the size of the public good both in the aggregate and per capita terms. Then, the public budget constraint implies that

$$
g=t .
$$

Using (1), (2), and (3), we can rewrite individual preferences as follows:

$$
U_{i}=g^{\alpha}\left(1-l_{i}\right)+y-g .
$$

This political jurisdiction has to decide, by majority rule, on the size and type of the public good. We make the following assumption on the voting process:

6. This is, of course, a restrictive assumption. One could generalize the model to a situation where individuals could move but with some costs. With moving costs complete stratification would not occur in theory, nor is it observed in practice. See Epple and Romer [1991] for the effect of mobility on voting on local public goods.

7. In the working paper version of this paper, we present an extension in which individual income is a function of the public good.

8. There is a connection here with the literature on revelation mechanisms which we do not explore. 
Assumption. Individuals vote first on the amount of taxation (thus on the size of the public good), and then on the type of the public good.

This assumption is made for tractability, in order to avoid issues of multidimensional voting, which is not our focus. Also, note that this order of voting resembles common budget procedures in which the size of the budget is decided before its composition. $^{9}$

We now solve the model backward, starting with the following result, which derives from a straightforward application of the median voter theorem, and is a slight generalization of a result by Alesina and Spolaore [1997].

PROPOSITION 1. For any positive amount of public good $g$, the type chosen is the one most preferred by the median voter.

Let us now consider the choice of the size of the public good $g$. Individual $i$ 's preferred size is given by the result of the following problem:

$$
\max U_{i}=g^{a}\left(l-\hat{l}_{i}\right)+y-g,
$$

where $\hat{l}_{i}$ is the distance of individual $i$ from the ideal type of median voter. This formulation incorporates the fact that the voters know that, after a decision is reached on the size of $g$, the type chosen is the one most preferred by the median voter. The solution of $(5)\left(g^{*}\right)$ is

$$
g_{i}^{*}=\left[a\left(1-\hat{l}_{i}\right)\right]^{1 /(1-a)} .
$$

Define $\hat{l}_{i}^{m}$ as the median distance from the type most preferred by the median voter-in short the "median distance from the median." A straightforward application of the median voter theorem implies the following result:

Proposition 2. The amount of public good provided in equilibrium is given by

$$
g^{*}=\left[a\left(1-\hat{l}_{i}^{m}\right)\right]^{1 /(1-a)} .
$$

From Proposition 2 a Corollary follows:

9. For a recent discussion of budget procedures, see the survey of the literature by Alesina and Perotti [1999]. 
CoRollary. The equilibrium amount of public good is decreasing in $\hat{l}_{i}^{m}$, the median distance from the median.

The median distance from the median can be considered an indicator of polarization of preferences, as illustrated in Figure I. Panel (a) shows a case of low median distance from the median; panel (b) shows a case of a larger median distance from the median. The picture of panel (b) is an example of a polarized society, with two separate groups with relatively homogeneous

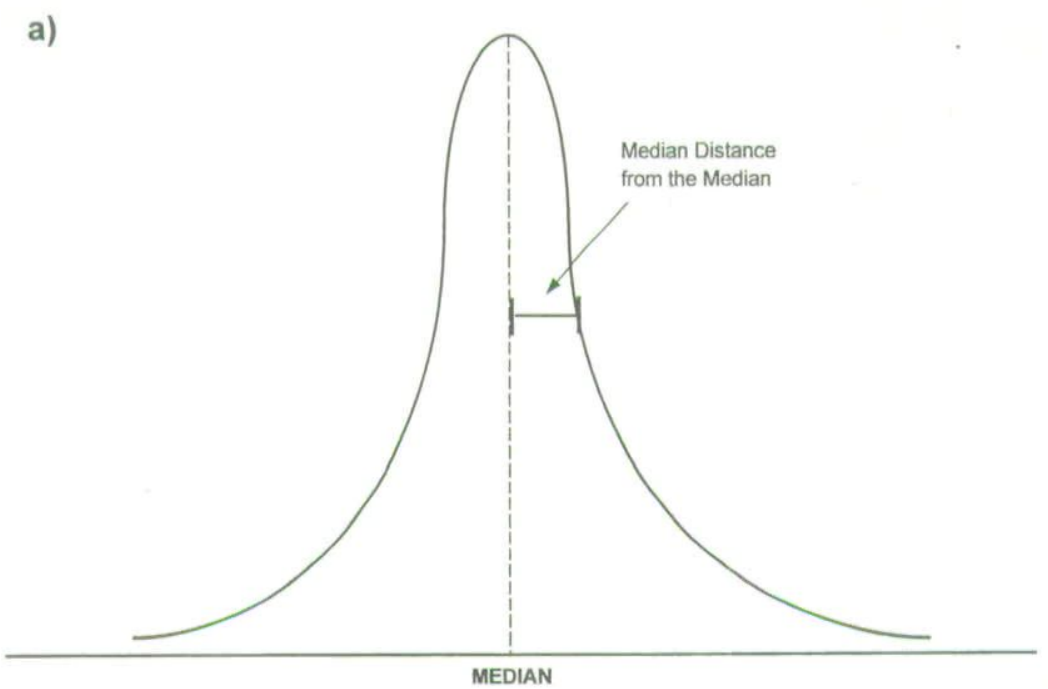

b)

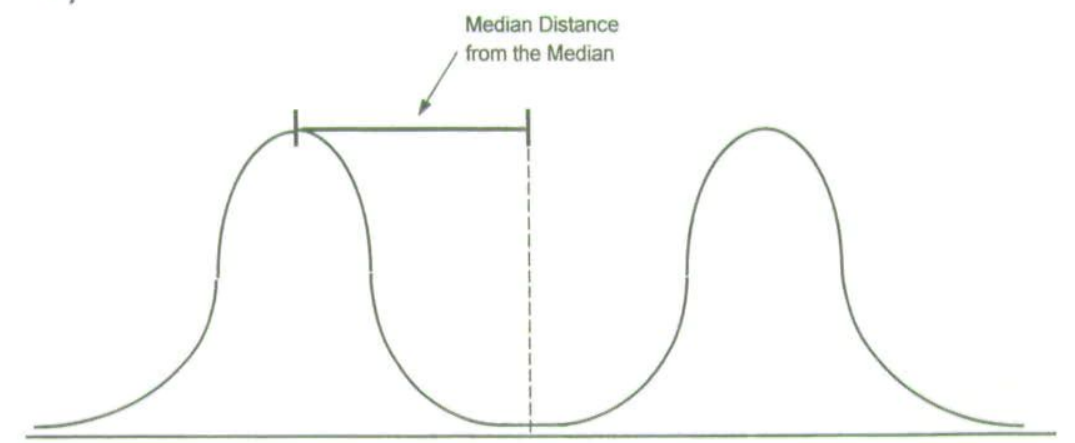

FIGURE I

Examples of Different "Median Distances from the Median" 
preferences within the group, but very distinct preferences across groups.

In summary, if $\hat{l}_{i}^{m}$ is high, a large fraction of the population have preferences that are very far from the chosen type of public good; therefore, they would prefer to keep taxes low and devote more resources to private consumption rather than public consumption. A jurisdiction with two (or more) polarized groups (like panel (b) of Figure I) is a prime example of high median distance from the median.

\section{B. Discussion}

We now discuss several issues not explicitly addressed in this basic simple model, and how to bring the model to the data.

In our theoretical model, the preference polarization that fuels interest group conflict is assumed, and is not related to ethnicity or race. In the empirical work that follows in the next sections, we use ethnic composition (which is easily observable) to capture conflicts among groups. We need to justify this choice.

Much scholarly and general writing suggests that preferences about public policy and ethnic origins are strongly correlated, and political conflicts over public policies are more and more often fought along ethnic dividing lines. Wilson [1996], Page [1996], Bell [1992], Hacker [1995], Kozol [1991], and Huckfeldt and Kohfeld [1989], among numerous others, argue that conflicts over public policy in general and public goods provisions in particular, are more and more determined by racial cleavages not class cleavages. Their titles are sufficiently eloquent: Two $\mathrm{Na}$ tions: Black and White, Separate, Hostile, and Unequal [Hacker] and Race and the Decline of Class in American Politics [Huckfeldt and Kohfeld]. ${ }^{10}$

For illustrative examples of polarized preferences over public goods, first consider language instruction in public schools. Without commenting on what is desirable public policy, let us describe the actual reaction of different ethnic groups to language instruction in, say, Oakland, California. Language is an issue for blacks

10. Huckfeldt and Kohfeld [1989] present several case studies of city politics with racial cleavages that are consistent with the spirit of our paper. An excellent example is their discussion of St. Louis in the early to mid-eighties [pp. 18-22]. As another polarization anecdote, they note that all-white precincts in the $1985 \mathrm{St}$. Louis mayoral election of a white against a black candidate voted for the white candidate by a margin of 40 to 1 . Many such examples exist: only 23 percent of white (usually Democratic) New Yorkers voted for the black Democratic mayoral incumbent David Dinkins; only 12 percent of (usually Democratic) Chicago whites voted for the black Democratic mayoral candidate in 1983 [Hacker 1995, p. 231]. 
in Oakland, as witness the recent furor over the proposal by the Oakland School Board that black English be recognized as a separate language ("Ebonics"). Although far from consensus on the Ebonics extreme, many blacks feel that inner city black children speaking nonstandard English have a right to programs that meet their needs. Many Hispanic parents complain of insufficient public resources for their children to get English as a Second Language classes or bilingual education. Many Hispanics reacted with hostility to the ill-fated Ebonics proposal as "a thinly veiled effort to grab bilingual funds.” Black parents responded that bilingual education has diverted resources away from addressing the special needs of their children. Asian parents in turn complain that Hispanic children get more bilingual resources than do their children. For their part, many whites have objected to the diversion of any resources to any nonstandard-English instruction. ${ }^{11}$ If all ethnic groups are dissatisfied, this may be a good indication of polarized groups who have wound up at an unhappy position in the middle. The result, according to our theoretical model, is that a jurisdiction spends less on public education than it would have in the absence of such polarization. ${ }^{12}$

Ethnic groups can have polarized preferences even over a seemingly neutral public good like highways. When ethnic groups are segregated within a city, these groups will have different travel patterns within the city. Then these groups will have different preferences for the location of major road arteries: each group wants the road arteries to be convenient to their own travel patterns. At the same time, no ethnic neighborhood itself wants to be bisected or isolated by an expressway. Kozol [1991, p. 180] argues that the Dan Ryan Expressway in Southside Chicago (built several decades ago) had a destructive effect on the Wentworth Avenue black neighborhood that was cut off from the rest of the city by the Expressway. Wilson [1996] also emphasizes how race relations have a significant impact on the choice of the geographical distributions of roads and urban transportation systems.

Thus, if, say, a white person perceives that a public good is

11. The "thinly veiled" quote is from Los Angeles Times, January 19, 1997, Part A, Page 1. This section is based largely on a series of articles by the LA Times during the "Ebonics" controversy. Note that Oakland is thirteenth in the nation on ETHNIC. There has not been complete white flight from the Oakland public schools, as the population of Oakland is about one-third white, while the share of private schools in enrollment is only 13 percent.

12. Goldin and Katz [1998] present evidence from the first part of this century consistent with this implication. 
enjoyed mostly by black citizens, he would oppose it precisely for that reason. In other words, the identity of the beneficiaries of the public good directly influences the utility level of each individual. This mechanism would reinforce the argument put forward in our model, namely that more ethnic fragmentation leads to fewer resources pooled together to provide nonexcludable public goods.

Finally, it is clear that ethnicity is not the only determinant of individual preferences over public goods. Certainly, income is another one; therefore, the distribution of income, in addition to ethnic fragmentation, could be an important determinant of the distribution of preferences over public goods. This is why in the empirical work we control for income distribution measures, in our attempt to isolate the effects of ethnic fragmentation. ${ }^{13}$

\section{Patronage, Budget Shares, and Fiscal Discipline}

Our simple model considered only one type of public expenditure, a nonexcludable public good. In practice, public expenditure can also be directed specifically to certain groups. For instance, think of targeted transfers, or public employment used for patronage. ${ }^{14}$ Interest group politics may lead to an increase in grouptargeted spending and patronage spending via "logrolling," and, by the arguments discussed above, a reduction in the provision of public goods. ${ }^{15}$ This consideration is important for the empirical analysis that follows, which focuses mostly on shares and to a lesser extent on levels of public goods. Suppose that public spending can be divided into two parts: one, labeled $g_{1}$, is mostly patronage; the other, $g_{2}$, is a nonexcludable public good, which only imperfectly can be targeted to specific groups. Total spending is $g=g_{1}+g_{2}$. An increase in group polarization and interest group politics would lead to a larger increase in $g_{1}$, which is almost pure patronage, relative to the increase in $g_{2}$, which is almost purely public. In fact $g_{2}$ may even decrease in level, if the public good element in it predominates. In other words, polarization would certainly lead to a decrease in the share of nonexcludable public goods on total spending, that is, the share $g_{2} /\left(g_{1}+g_{2}\right)$ is decreasing in polarization. However, to the extent that even $g_{2}$ can be

13. Meltzer and Richards [1981] are a "classic" reference on the effect of income distribution on the social choice of the size of redistributive programs.

14. See Alesina, Baqir, and Easterly [1997] for a discussion of the effect of ethnic fragmentation on employment in U. S. cities.

15. A vast literature has discussed how interest group pressure leads to an increase in spending specifically targeted to certain special interests. A classic reference is Weingast, Shepsle, and Johnsen [1981]. 
targeted to specific groups, the level of $g_{2}$ may actually increase with interest group politics. Thus, we have stronger implications for the effects of polarization on the share of spending on pure public goods than on their level. Finally, the implications of different levels of polarization on total government spending are ambiguous, because of the opposite effect of pressure for more group-specific spending programs, and fewer nonexcludable public goods.

Our model is static, and has no implication for the budget balance. However, a related literature suggests that sociopolitical fragmentation may lead to conflicts over the allocation of the tax burden that may lead to the postponement of deficit reduction policies. ${ }^{16}$ The empirical evidence supportive of this view is drawn from OECD countries and U. S. states. ${ }^{17}$ In the empirical analysis below we will check whether ethnic fragmentation at the local level has any implication for the fiscal balance of local governments.

The implications of the above theoretical discussion are as follows: 1) the composition of public spending is a function of ethnic fragmentation: the share of public goods spending is lower in more ethnically fragmented localities; 2) the sign of the correlation between the size of government spending and ethnic fragmentation is not determined a priori, since transfers and patronage spending may be positively related to ethnic fragmentation and public goods negatively related to the same variable; 3 ) fiscal discipline is more problematic in ethnically fragmented localities.

\section{The EMPIRICAL Evidence}

We test our hypotheses with three cross-section samples of public goods spending in U. S. urban localities: cities, metropolitan areas, and counties.

\section{A. Data and Sources}

We use the ethnic fractionalization (ETHNIC) index as a measure of ethnic fragmentation. ETHNIC measures the probability that two randomly drawn people from a city, county, or

16. For theoretical models with this implication see Alesina and Drazen [1991] and Velasco [1994].

17. See Roubini and Sachs [1989], Alesina and Perotti [1995], and Kontopoulos and Perotti [1997] on OECD countries and Poterba [1994] and Alt and Lowry [1994] on U. S. states. 
metropolitan area belong to different ethnic groups. ${ }^{18}$ Specifically, we consider the population distribution by race, and we construct ETHNIC as follows:

$$
\text { ETHNIC }=1-\sum_{i}\left(\text { Race }_{i}\right)^{2},
$$

where Race $_{i}$ denotes the share of population self-identified as of race $i$ and

$$
\begin{aligned}
& i=[\text { White, Black, } \\
& \quad \text { Asian and Pacific Islander, American Indian, Other } \mid .
\end{aligned}
$$

We follow the racial classification used by the U. S. Census. These classifications are somewhat arbitrary, but they also reflect which ethnic groupings are politically salient. Note that "Hispanic" is not a mutually exclusive category with these racial classifications in the Census; Hispanic is reported separately as the answer to a different question on "origin." However, there is a high correlation $(0.9)$ between "Hispanic" and "Other" in the above classification. Many Hispanics apparently respond Other because they do not feel accurately represented in the multiple racial choice provided by the Census. ${ }^{19}$ For practical purposes, then, the category Other is essentially Hispanic.

We made an effort to collect data at different levels of aggregation-cities, metropolitan areas, and counties-for three reasons. First, there is going to be far more Tiebout sorting between city and suburb of one metropolitan area than between different metropolitan areas. Comparing the results at different levels of aggregation will give us some idea of the possible biases introduced by Tiebout sorting (although we also use instruments for possibly endogenous right-hand-side variables). Second, none of the data sets have an exact match between the unit of observation and the relevant jurisdiction for voting on the public good for all types of public goods. Different types of public goods have different jurisdictions, and the jurisdictions themselves are politically determined. Testing all of our results at different levels

18. This is the same measure used for linguistic groups in nations by Canning and Fay [1993], Mauro [1995], Easterly and Levine [1996], and many others.

19. Data are available from some states on the matching between Hispanic and Other. In California in 1990, 49.5 percent of Hispanics chose one of the existing racial categories and 50.5 percent chose Other. Ninety-two percent of Hispanics who chose a racial category in California chose White [Hacker 1995, p. 6, 253]. When Hispanics respond to the race question with White or Black rather than Other, it may suggest they identify more with that ethnic category than with being Hispanic - which is what is relevant for our purposes. 
of jurisdiction will give us some idea whether the results are affected by these problems. Third, and most prosaically, some variables have data at one jurisdictional level but not at others.

Our county, metropolitan, and city data come from the County and City Data Book, 1994 (CCD) published by the Bureau of the Census. ${ }^{20}$ This publication provides data on a variety of subjects for a cross section of U. S. counties, metropolitan areas, cities, and places. "Cities" in the source are incorporated places that had a 1990 population of 25,000 or more. Expenditures are assigned to the governmental level that executes them, regardless of whether they are financed by transfers from higher levels of government. ${ }^{21}$ Nearly all the data in this publication come from the Bureau of the Census and other federal agencies. Most of our data refer to the year 1990, unless otherwise stated, and use the city and county data files. Especially for metropolitan and county data, we have supplemented CCD with data from the publication City and County Plus (CCP). ${ }^{22}$

Our city sample, which includes places with 25,000 population and above, is 1020 observations. As described in the Appendix, we systematically checked each data set by sorting each variable and examining extreme values. Our metro areas sample consists of 304 observations. The county sample is 1386 observations. Because we are focusing on urban public goods, we have excluded sparsely populated rural counties; we chose a county population cutoff of 25,000 to match the CCD's cutoff for cities. ${ }^{23}$

Less systematically, we looked at whether the data made sense based on our (admittedly superficial) knowledge of U.S. cities. We note, for example, that the top seven cities for share of the population with a college degree are all college towns. ${ }^{24}$ The

20. Electronically we obtained the data from their CD-ROM version.

21. See the Data Appendix for more details. We obtained these definitions from the statistical publications mentioned below and from a long, albeit nearly incomprehensible, document called the Government Finance and Employment Classification Manual [Census Bureau 1992].

22. Available from Slater Hall Information Products in both hard copy and CD ROM. We obtain data from earlier years from City and County Compendium (CCC), distributed on CD ROM by Slater Hall Information Products.

23 . Note that there are counties with as few as 52 inhabitants! We omitted a small number of observations in each sample that a priori made no sense-such as zero city government spending in a couple of cities - as described in the Data Appendix. In any case, our results are robust to simply using the full available sample without removing any data anomalies (although we think it is better to remove observations that do not make sense). Results obtained using all the observations are available and are virtually identical to those presented in the text.

24. In decreasing rank, East Lansing, MI, Chapel Hill, NC, West Lafayette, IN, State College, PA, Palo Alto, CA, Ann Arbor, MI, and Davis, CA. 
two cities with the highest income inequality are Beverly Hills, $\mathrm{CA}$, and Miami Beach, FL. Beverly Hills is also the richest city with an income that is ten times that of the poorest-Pharr, TX. The top recipient of intergovernmental transfers is Washington, DC, and this city also has the largest deficit before transfers (New York City is close behind Washington, DC, in these categories).

Table I reports the names and definitions of all the variables used in this paper. Table II reports summary statistics for the city sample. Analogous tables for the other samples are reported in the Appendix. In the city sample, our measure of ethnic fragmentation, ETHNIC, ranges from .014 (for Gloucester, MA) to .73 (for Carson, CA) ${ }^{25}$ For the sample of metropolitan areas, ETHNIC ranges from .024 (Dubuque, IA) to .61 (Los Angeles-Long Beach, CA) with a median of .247 . For the County sample ETHNIC ranges from .007 (Wayne County, WV) to .677 (Bronx County, NY).

\section{B. Results}

We discuss the controls we will use, present results of different local fiscal variables regressed on ETHNIC and controls, and then discuss some sensitivity checks.

We are interested in the effect of ethnic fractionalization (ETHNIC) on various fiscal variables. For each regression, in addition to ETHNIC, we include control variables. Our first control variable is income per capita, since more developed, richer cities may have more public goods. Our second control is city size, for which we use the log of 1990 population. The relationship between public goods and ethnic fragmentation may be driven by city size-with big cities being more fragmented and having "ghettos." Also there are important scale factors in public goods. Educational attainment might be another possible omitted variable from our model, with more educated cities choosing better city policies, demanding more education for their children, or monitoring the provision of their public goods. For educational attainment we use BAGRAD, which is the fraction of population aged 25 or over who have completed college or a higher degree.

The next control is income inequality. One may argue that polarization of preferences is a function of polarization of income levels, rather than race. Therefore, income inequality, not ethnic fragmentation, might explain the pattern of provision of public

25. Since we have five ethnic groups, the maximum that ETHNIC could theoretically reach in our framework is .8, which would occur if each of the five ethnic groups accounted for 20 percent of the population. 


\author{
TABLE I \\ VARIABLE DEFINITIONS
}

OBSERVATIONS ARE FOR 1990 UNLESS OTHERWISE NOTED

\begin{tabular}{ll}
\hline \hline & \multicolumn{1}{c}{ Ethnicity } \\
\hline $\begin{array}{l}\text { Ethnic fractional- } \\
\text { ization }\end{array}$ & $\begin{array}{c}\text { Measures the probability that two persons drawn randomly } \\
\text { from the population belong to different self-identified } \\
\text { ethnic groups (white, black, American Indian, Asian, and } \\
\text { other), hence ranges from 0 (complete homogeneity) to 1 } \\
\text { (complete heterogeneity) }\end{array}$ \\
$\begin{array}{l}\text { Ethnic fractionaliz. } \\
1980\end{array}$ & $\begin{array}{l}\text { Ethnic Fractionalization Index in 1980 } \\
\text { Black }\end{array}$ \\
$\begin{array}{l}\text { American Indian, fraction of total population } \\
\text { American Indian, Eskimo, or Aleut (fraction of total popula- } \\
\text { tion) }\end{array}$ \\
$\begin{array}{l}\text { Asian } \\
\text { Other race }\end{array}$ \\
$\begin{array}{c}\text { Not Black, American Indian, Asian, or White (fraction of } \\
\text { total population); proxy for Hispanic }\end{array}$ \\
White & White, fraction of total population
\end{tabular}

Government

Intergovt revenue per capita

Taxes per capita

Surplus per capita

Surplus per capita before transfers

Debt per capita

Expenditure per capita

Share of spending on health

Share of spending on education

Share of spending on police

Share of spending on fire protection

Share of spending on roads

Share of spending on welfare

Share of spending on sewerage and trash pickup

Spending on roads per capita
Revenue from transfers from higher levels of government, per capita, 1990-1991

Total local government taxes per capita, 1990-1991

Per capita local government surplus

Per capita local government surplus excluding intergovernmental transfers from revenue

Per capita local government debt outstanding

General local government expenditure per capita, 19901991

Fraction of general local government expenditure for health and hospitals

Fraction of general local government expenditure for education (metro and county only)

Percent of general local government expenditure for police protection

Fraction of general local government expenditure for fire protection (available for cities only)

Fraction of general local government expenditure for highways

Fraction of local government direct general expenditures for public welfare (metro and county only)

Fraction of general local government expenditure for sewerage and trash pickup (available for cities only)

Per capita expenditure on highways 
TABLE I

(CONTINUED)

Income, education, and population

\begin{tabular}{ll}
$\begin{array}{c}\text { Number of house- } \\
\text { holds }\end{array}$ & Number of households \\
$\begin{array}{c}\text { Fraction of popula- } \\
\text { tion }>65\end{array}$ & Fraction of population that is 65 years or older \\
$\begin{array}{c}\text { Log of population } \\
\text { Median household }\end{array}$ & $\begin{array}{l}\text { Log of population } \\
\text { Median household money income, } 1989\end{array}$ \\
income & \\
$\begin{array}{c}\text { Income per capita } \\
\text { Income per capita, }\end{array}$ & Per capita money income, 1989 \\
1979 & Per capita money income, 1979 \\
$\begin{array}{c}\text { Percentage BA } \\
\text { graduates }\end{array}$ & $\begin{array}{c}\text { Persons } 25 \text { years and over, fraction with Bachelor's degree } \\
\text { or higher }\end{array}$ \\
$\begin{array}{c}\text { Mean to median } \\
\text { income ratio }\end{array}$ & $\begin{array}{c}\text { Ratio of mean to median household income, constructed } \\
\text { from above variables }\end{array}$ \\
\hline
\end{tabular}

goods. Our measure of income inequality is the ratio of the mean household income to the median household income in a jurisdiction. ${ }^{26}$ We will later add the poverty rate as a robustness check.

We also control for the age structure, measured as the percentage of population that is 65 or older. The empirical local public good literature, briefly reviewed above, has emphasized the role of age structure as a determinant of preferences for public goods, most obviously for education.

Table III illustrates our approach with the example of a regression for the city's share of spending on roads. The share of city spending on roads decreases with higher ethnic diversity: in all the regressions the coefficient on ETHNIC is highly significant with $t$-statistics ranging from -4.7 to -8.7 . The magnitude of the coefficient has a nice shorthand interpretation in this and in all the other regressions: it is the amount by which the dependent variable (in this case fraction of city spending on roads) would change going from complete ethnic homogeneity $(\mathrm{ETHNIC}=0)$ to complete heterogeneity $(\mathrm{ETHNIC}=1) .{ }^{27}$ Hence, a move from complete homogeneity to heterogeneity would lower the roads

26. Note that this is the theoretically appropriate measure of income inequality in any model based upon the median voter theorem applied to fiscal decisions.

27. Remember, however, that complete heterogeneity is not possible in our data because we have only five ethnic groups-constraining ETHNIC to a maximum of .8-we mention this interpretation only because of its heuristic ease, 
TABLE II

Summary Statistics on City Data

\begin{tabular}{|c|c|c|c|c|c|c|c|}
\hline Variable name & Mean & Median & Min. & Max. & $\begin{array}{l}\text { Std. } \\
\text { dev. }\end{array}$ & $\begin{array}{l}\text { No. of } \\
\text { obs. }\end{array}$ & Unit \\
\hline American Indian & 0.01 & 0.00 & 0.00 & 0.14 & 0.01 & 1076 & Fraction \\
\hline Asian & 0.04 & 0.02 & 0.00 & 0.84 & 0.08 & 1076 & Fraction \\
\hline Percentage BAgraduates & 0.23 & 0.20 & 0.02 & 0.71 & 0.12 & 1076 & Fraction \\
\hline Black & 0.12 & 0.04 & 0.00 & 0.98 & 0.16 & 1076 & Fraction \\
\hline Ethnic fractionalization & 0.29 & 0.28 & 0.01 & 0.73 & 0.17 & 1076 & Fraction \\
\hline Expenditure per capita & 876 & 710 & 161 & 7154 & 561 & 1020 & $\begin{array}{l}\text { \$ per } \\
\quad \text { capita }\end{array}$ \\
\hline $\begin{array}{l}\text { Share of spending on } \\
\text { police }\end{array}$ & 0.16 & 0.15 & 0.00 & 0.48 & 0.07 & 1020 & Fraction \\
\hline $\begin{array}{l}\text { Share of spending on fire } \\
\text { protection }\end{array}$ & 0.09 & 0.09 & 0.00 & 0.25 & 0.05 & 1020 & Fraction \\
\hline $\begin{array}{l}\text { Share of spending on } \\
\text { roads }\end{array}$ & 0.11 & 0.10 & 0.01 & 0.43 & 0.07 & 1020 & Fraction \\
\hline $\begin{array}{l}\text { Share of spending on sew- } \\
\text { erage and trash pickup }\end{array}$ & 0.13 & 0.12 & 0.00 & 0.67 & 0.09 & 1020 & Fraction \\
\hline $\begin{array}{l}\text { Spending on roads per } \\
\text { capita }\end{array}$ & 81 & 68 & 2 & 371 & 51 & 1020 & $\begin{array}{l}\$ \text { per } \\
\text { capita }\end{array}$ \\
\hline $\begin{array}{l}\text { Mean to median income } \\
\text { ratio }\end{array}$ & 1.26 & 1.24 & 1.03 & 2.25 & 0.14 & 1076 & Ratio \\
\hline Income per capita & 14,861 & 13,682 & 5,561 & 55,463 & 5,002 & 1076 & $\begin{array}{l}\text { \$ per } \\
\text { capita }\end{array}$ \\
\hline Other race & 0.05 & 0.01 & 0.00 & 0.67 & 0.08 & 1076 & Fraction \\
\hline $\begin{array}{l}\text { Fraction of population } \\
>65\end{array}$ & 0.12 & 0.12 & 0.02 & 0.49 & 0.05 & 1076 & Fraction \\
\hline Log of population & 10.97 & 10.76 & 10.13 & 15.81 & 0.77 & 1076 & $\begin{array}{l}\text { Log of \# } \\
\text { people }\end{array}$ \\
\hline $\begin{array}{l}\text { Intergovt revenue per } \\
\text { capita }\end{array}$ & 209 & 123 & 1 & 2456 & 245 & 1020 & $\begin{array}{l}\$ \text { per } \\
\text { capita }\end{array}$ \\
\hline $\begin{array}{l}\text { Surplus (after transfers) } \\
\text { per capita }\end{array}$ & -21 & -6 & -1866 & 677 & 142 & 1020 & $\begin{array}{l}\$ \text { per } \\
\text { capita }\end{array}$ \\
\hline $\begin{array}{l}\text { Surplus (before transfers) } \\
\text { per capita }\end{array}$ & -230 & -149 & -2321 & 411 & 286 & 1020 & $\begin{array}{l}\text { \$per } \\
\text { capita }\end{array}$ \\
\hline Taxes per capita & 373 & 296 & 38 & 3978 & 276 & 1020 & $\begin{array}{l}\text { \$ per } \\
\text { capita }\end{array}$ \\
\hline White & 0.79 & 0.84 & 0.02 & 0.99 & 0.18 & 1076 & Fraction \\
\hline
\end{tabular}

spending share by around .09 (nine percentage points). In terms of our sample variation, a one-standard-deviation change in ETHNIC would change the share of spending on roads by one-quarter of a standard deviation.

ETHNIC remains significant after including control variables. The share of spending on roads is inversely related to 
TABLE III

Dependent Variable Is Expenditure Share on Roads, City Sample

\begin{tabular}{lcccccc}
\hline \hline \multicolumn{1}{c}{ RHS var. } & 1 & 2 & 3 & 4 & 5 & 6 \\
\hline Constant & 0.14 & 0.12 & 0.18 & 0.18 & 0.29 & 0.28 \\
& $(31.44)$ & $(14.07)$ & $(7.35)$ & $(7.40)$ & $(9.33)$ & $(9.22)$ \\
Ethnic fractionalization & -0.098 & -0.090 & -0.080 & -0.079 & -0.060 & -0.083 \\
& $(-8.69)$ & $(-7.68)$ & $(-6.39)$ & $(-6.34)$ & $(-4.72)$ & $(-6.38)$ \\
Income per capita & & $1.11 \mathrm{E}-06$ & $1.14 \mathrm{E}-06$ & $7.00 \mathrm{E}-07$ & $-1.47 \mathrm{E}-07$ & $9.34 \mathrm{E}-07$ \\
& & $(2.52)$ & $(2.56)$ & $(1.30)$ & $(-0.26)$ & $(1.70)$ \\
Log of population & & & -0.006 & -0.006 & -0.006 & -0.006 \\
& & & $(-2.66)$ & $(-2.72)$ & $(-2.62)$ & $(-2.86)$ \\
Percentage BAgraduates & & & & 0.028 & 0.085 & 0.007 \\
& & & & $(1.25)$ & $(3.42)$ & $(0.26)$ \\
Mean to median income & & & & & -0.096 & -0.047 \\
$\quad$ ratio & & & & & $(-6.03)$ & $(-2.86)$ \\
Fraction of population & & & & & & -0.253 \\
$\quad>65$ & 1020 & 1020 & 1020 & 1020 & 1020 & 1020 \\
No. of obs. & 0.07 & 0.07 & 0.07 & 0.07 & 0.11 & 0.13 \\
Adj $R^{2}$ &
\end{tabular}

Heteroskedasticity-corrected $t$-statistics are in parentheses.

population size, to income inequality, and to age structure. We now present all our results organized by groups of related variables.

Table IV (like Table V which will follow) is organized in this way: the first column identifies the dependent variable. The following two columns report the coefficients and the $t$-statistics of the variable ETHNIC in two different regressions that are identical to regression 1 (no controls) and regression 6 (all controls) reported in full in Table III. ${ }^{28}$ We report in Table IV our results for all three samples: cities, metropolitan areas, and counties. The control variables are the same in all three samples. The only difference is that for metropolitan areas and counties we present results using two-stage-least squares. We instrument for both ETHNIC and income per capita, using the values of ETHNIC and income per capita in 1979-1980. Results using OLS are similar and are available upon request. We did not have the earlier data to use as instruments for the city sample. When a dependent variable does not appear in all three samples, it is because of data

28. For the sake of completeness we also report in this table the regressions on the expenditure share on roads, which are, of course, identical to those of Table III. We have also checked that the results on ETHNIC are robust to adding one control variable at a time, like in Table III. Our results are indeed robust. 
TABLE IV

Coefficients on ETHNiC in Two Regressions for Expenditure Shares

\begin{tabular}{|c|c|c|c|c|}
\hline \multirow[b]{2}{*}{ Dependent variable: } & \multicolumn{2}{|c|}{ Regressions } & \multirow[b]{2}{*}{ \#obs } & \multirow[b]{2}{*}{ Adj. $R^{2}$} \\
\hline & $\begin{array}{l}1 \text { (no } \\
\text { controls) }\end{array}$ & $\begin{array}{l}6 \text { (all } \\
\text { controls) }\end{array}$ & & \\
\hline \multicolumn{5}{|l|}{ City } \\
\hline Share of spending on roads & $\begin{array}{l}-0.098 \\
(-8.69)\end{array}$ & $\begin{array}{l}-0.083 \\
(-6.38)\end{array}$ & 1020 & 0.13 \\
\hline $\begin{array}{l}\text { Share of spending on sewerage and trash } \\
\text { pickup }\end{array}$ & $\begin{array}{l}-0.047 \\
(-2.97)\end{array}$ & $\begin{array}{l}-0.079 \\
(-4.34)\end{array}$ & 1020 & 0.09 \\
\hline Share of spending on police & $\begin{array}{l}0.057 \\
(4.58)\end{array}$ & $\begin{array}{l}0.099 \\
(7.37)\end{array}$ & 1020 & 0.10 \\
\hline Share of spending on fire protection & $\begin{array}{l}-0.002 \\
(-0.18)\end{array}$ & $\begin{array}{l}-0.004 \\
(-0.40)\end{array}$ & 1020 & 0.05 \\
\hline Spending on roads per capita & $\begin{array}{r}-36.4 \\
(-4.30)\end{array}$ & $\begin{array}{r}-37.0 \\
(-3.59)\end{array}$ & 1020 & 0.08 \\
\hline \multicolumn{5}{|l|}{ Metro } \\
\hline Share of spending on roads & $\begin{array}{l}-0.076 \\
(-9.14)\end{array}$ & $\begin{array}{l}-0.058 \\
(-4.84)\end{array}$ & 304 & 0.22 \\
\hline Share of spending on police & $\begin{array}{l}0.024 \\
(4.26)\end{array}$ & $\begin{array}{l}0.020 \\
(2.39)\end{array}$ & 304 & 0.18 \\
\hline Share of spending on education & $\begin{array}{l}-0.145 \\
(-4.21)\end{array}$ & $\begin{array}{l}-0.174 \\
(-3.62)\end{array}$ & 304 & 0.17 \\
\hline Share of spending on health & $\begin{array}{l}0.219 \\
(5.46)\end{array}$ & $\begin{array}{l}0.269 \\
(4.03)\end{array}$ & 304 & 0.10 \\
\hline Share of spending on welfare & $\begin{array}{l}-0.030 \\
(-1.73)\end{array}$ & $\begin{array}{l}-0.047 \\
(-2.62)\end{array}$ & 304 & 0.01 \\
\hline Spending on roads per capita & $\begin{array}{r}-137 \\
(-7.19)\end{array}$ & $\begin{array}{r}-111 \\
(-4.44)\end{array}$ & 304 & 0.15 \\
\hline \multicolumn{5}{|l|}{ County } \\
\hline Share of spending on roads & $\begin{array}{r}-0.076 \\
(-15.72)\end{array}$ & $\begin{array}{l}-0.055 \\
(-9.26)\end{array}$ & 1386 & 0.21 \\
\hline Share of spending on police & $\begin{array}{r}0.031 \\
(10.96)\end{array}$ & $\begin{array}{r}0.038 \\
(10.44)\end{array}$ & 1386 & 0.20 \\
\hline Share of spending on education & $\begin{array}{l}-0.109 \\
(-5.27)\end{array}$ & $\begin{array}{l}-0.103 \\
(-4.18)\end{array}$ & 1386 & 0.13 \\
\hline Share of spending on health & $\begin{array}{l}0.138 \\
(6.78)\end{array}$ & $\begin{array}{c}0.125 \\
(5.02)\end{array}$ & 1386 & 0.07 \\
\hline Share of spending on welfare & $\begin{array}{l}-0.043 \\
(-6.41)\end{array}$ & $\begin{array}{l}-0.051 \\
(-7.03)\end{array}$ & 1386 & 0.05 \\
\hline Spending on roads per capita & $\begin{array}{r}-139 \\
(-13.29)\end{array}$ & $\begin{array}{r}-96 \\
(-7.20)\end{array}$ & 1386 & 0.11 \\
\hline
\end{tabular}

Regressions 1 and 6 include the set of control variables that are in regressions 1 and 6 in Table III. Heteroskedasticity-corrected $t$-statistics are in parentheses. 
availability. The pattern of results on the other control variables is reasonable. ${ }^{29}$

The results on ETHNIC are quite striking. ETHNIC is negatively associated with the share in the budget of three "productive" public goods: education, roads, and sewerage and trash pickup. We consider this result to be the main empirical result of the paper, since these are the variables for which the theory made an unambiguous prediction, as discussed in subsection II.C.

The roads result for cities was already featured in Table III. We now see that this result on roads is robust across all three samples. We also estimate the effect of ETHNIC on the level of roads spending per capita rather than as a share of the budget; although theoretically ambiguous, this effect is negative and significant in all three samples. The other levels results also usually have the same sign and significance as the corresponding share variable. ${ }^{30}$

The share of spending for welfare is also negatively associated with ETHNIC in both the metro and county samples (the only samples for which it is available), even though in the metro area sample the bivariate association is only marginally significant at conventional levels. A one-standard-deviation increase in ETHNIC is associated with a fifth of a standard deviation decrease in the share of welfare spending. We speculate that

29. To anticipate the most robust effects of the other control variables across all our regressions: income has a positive effect on the share of spending on police, road spending per capita, local education revenue collected per student, and taxes and spending per capita. Local income has a negative effect on federal and state education revenue per pupil. Population size has a positive effect on education spending per pupil, taxes per capita, federal, state, and local revenue per pupil, and a negative effect on share of health spending. The fraction with a college degree has a negative effect on intergovernmental transfers, and a positive effect on education revenue collected per student. Inequality has a negative effect on education spending per pupil. The percent of the population 65-and-up has a positive effect on education spending per pupil (oddly enough) but a negative effect on the share of spending going to education. Complete results are available upon request.

30. In the county sample with the full set of controls, health spending per capita and police spending per capita are significantly and positively related to ETHNIC, while education spending per pupil and welfare spending per capita were significantly and negatively related to ETHNIC. In other words, all the level variables have the same signs and significance as the share variables in the county sample. In the metro sample also, all the level variables have the same sign as the share variables, and all are significant except for welfare spending per capita. In the city sample, ETHNIC is negative but insignificant for sewerage spending per capita, and significantly positive for fire protection spending per capita and police spending per capita. 
ethnic groups dislike redistributive programs that favor other groups. ${ }^{31}$

The share of expenditure on police increases with ETHNIC, in all three samples. Police spending obviously has something to do with crime, and indeed the size and significance of this coefficient would be reduced if we controlled for crime. The correlation across cities between ETHNIC and violent crimes per capita is .48. We regard crime as endogenous to public goods quantity, income, income distribution, and ethnic diversity, and so is one of the channels through which these other variables influence public choices. In any event, in the sensitivity discussion below we will control for crime.

Spending on health and hospitals increases with ETHNIC in the metro and county samples (this item does not usually show up in city budgets and so is not in the city sample). We are not sure why this item, which includes a mixture of public goods provision and transfers in the form of subsidized health services, is positively related to ETHNIC.

Of course, if most, but not all (remember police), shares are going down with ETHNIC, some other shares must be going up. The categories of spending that Table IV includes account for, on average, 73 percent of the budget in the county sample, 67 percent of the budget in metro areas, and 51 percent of the budget in cities. The residual includes interest payments on debt and various poorly classified and described discretionary programs. This "other" unidentified spending could include "patronage," although we have no direct evidence that this is so. However, the looseness in the definition of these other programs may indicate room for patronage spending. We find in the city and county resultsalthough not in the metro sample-that this residual share is positively, significantly, and robustly related to ETHNIC.

Table V reports results on aggregate fiscal variables: intergovernmental transfers, deficits and debt, total spending, and total revenues. ETHNIC is positively associated with more intergovernmental transfers in the city, metro, and county samples (although only the bivariate association is significant in the city and metro samples). Namely, more ethnically fragmented localities receive more transfers per capita from higher levels of government, even

31. Page [1996, p. 247] cites a 1986 poll in which 17 percent of whites supported increased spending on programs that primarily assisted blacks, compared with 74 percent of blacks. See also Luttmer [1997] for recent evidence on this point. 
TABLE V

CoEfFicients on ETHNIC in Six REgRessions FoR Fiscal Aggregates

\begin{tabular}{|c|c|c|c|c|}
\hline \multirow{2}{*}{ Dependent variable: } & \multicolumn{2}{|c|}{ Regressions } & \multirow[b]{2}{*}{ \#obs } & \multirow[b]{2}{*}{ Adj. $R^{2}$} \\
\hline & 1 (no controls) & 6 (all controls) & & \\
\hline \multicolumn{5}{|c|}{$\underline{\text { Government balances }}$} \\
\hline Intergovt revenue per capita & $\begin{array}{l}174.7 \\
(3.45)\end{array}$ & $\begin{array}{r}64.1 \\
(1.39)\end{array}$ & 1020 & 0.07 \\
\hline Surplus (after transfers) per capita & $\begin{array}{r}-39.8 \\
(-1.69)\end{array}$ & $\begin{array}{r}-78.3 \\
(-2.77)\end{array}$ & 1020 & 0.01 \\
\hline Surplus (before transfers) per capita & $\begin{array}{l}-214.5 \\
(-3.81)\end{array}$ & $\begin{array}{l}-142.3 \\
(-2.55)\end{array}$ & 1020 & 0.05 \\
\hline Metro & & & & \\
\hline Intergovt revenue per capita & $\begin{array}{r}269 \\
(2.11)\end{array}$ & $\begin{array}{r}24 \\
(0.15)\end{array}$ & 304 & 0.08 \\
\hline Surplus (after transfers) per capita & $\begin{array}{r}96 \\
(1.79)\end{array}$ & $\begin{array}{r}6 \\
(0.07)\end{array}$ & 304 & 0.02 \\
\hline Surplus (before transfers) per capita & $\begin{array}{r}-173 \\
(-1.35)\end{array}$ & $\begin{array}{r}-18 \\
(-0.12)\end{array}$ & 304 & 0.06 \\
\hline Debt per capita & $\begin{array}{r}1438 \\
(2.95)\end{array}$ & $\begin{array}{r}1117 \\
(1.83)\end{array}$ & 303 & 0.17 \\
\hline \multicolumn{5}{|l|}{ County } \\
\hline Intergovt revenue per capita & $\begin{array}{r}293 \\
(5.54)\end{array}$ & $\begin{array}{r}166 \\
(2.60)\end{array}$ & 1385 & 0.05 \\
\hline Surplus (after transfers) per capita & $\begin{array}{r}44 \\
(1.15)\end{array}$ & $\begin{array}{r}23 \\
(0.48)\end{array}$ & 1385 & 0.003 \\
\hline Surplus (before transfers) per capita & $\begin{array}{r}-115 \\
(-2.65)\end{array}$ & $\begin{array}{r}-50 \\
(-0.80)\end{array}$ & 1396 & 0.01 \\
\hline Debt per capita & $\begin{array}{r}837 \\
(1.88)\end{array}$ & $\begin{array}{r}1079 \\
(2.24)\end{array}$ & 1386 & 0.01 \\
\hline \multicolumn{5}{|c|}{$\underline{\text { Taxes, spending }}$} \\
\hline Taxes per capita & $\begin{array}{l}184.1 \\
(3.25)\end{array}$ & $\begin{array}{l}150.0 \\
(2.73)\end{array}$ & 1020 & 0.17 \\
\hline Expenditure per capita & $\begin{array}{l}506.0 \\
(4.44)\end{array}$ & $\begin{array}{l}317.9 \\
(2.96)\end{array}$ & 1020 & 0.12 \\
\hline Metro & & & & \\
\hline Taxes per capita & $\begin{array}{r}-140 \\
(-1.27)\end{array}$ & $\begin{array}{r}-173 \\
(-1.61)\end{array}$ & 304 & 0.53 \\
\hline Expenditure per capita & $\begin{array}{r}497 \\
(2.11)\end{array}$ & $\begin{array}{r}420 \\
(1.33)\end{array}$ & 304 & 0.21 \\
\hline County & & & & \\
\hline Taxes per capita & $\begin{array}{r}-172 \\
(-2.80)\end{array}$ & $\begin{array}{r}-47 \\
(-0.97)\end{array}$ & 1386 & 0.45 \\
\hline Expenditure per capita & $\begin{array}{r}365 \\
(3.16)\end{array}$ & $\begin{array}{r}400 \\
(3.35)\end{array}$ & 1386 & 0.15 \\
\hline
\end{tabular}

Regressions 1 through 6 include the set of control variables that are in regressions 1 through 6 in Table III. Heteroskedasticity-corrected $t$-statistics are in parentheses. 
after controlling for the level of income and its distribution. Why this is the case is an interesting politico-economic question. One interpretation could be that the higher levels of governments try to compensate ethnically fragmented communities precisely because of the difficulties that the latter have in directing local resources to the supply of public goods. A more cynical explanation is that more ethnically fragmented localities have more pressure groups that can lobby for support from higher levels of government. ${ }^{32}$

There is some evidence that the fiscal balance before intergovernmental transfers tends to be worse in more ethnically fragmented localities, although this result is not robust across samples. The only robust result on this point comes from the city sample. Remember that the theory was ambiguous on this point. More ethnically fragmented cities have a larger deficit (or smaller surplus) even after intergovernmental transfers, even though the latter are positively associated with fragmentation. Although the deficit result was not robust in metropolitan areas and counties, those samples feature a related robust result that accumulated local debt is positively associated with ETHNIC.

Total spending is significantly and positively associated with ETHNIC in all three samples. For example, in the city sample, a one-standard-deviation increase in ETHNIC is associated with one-seventh of a standard deviation increase in spending per capita. A move from zero to complete heterogeneity would imply an increase in spending per capita of $400-500$ dollars. This would support the logrolling extension of the theory we discussed in the theoretical subsection II.C.

The results on local tax revenues are not consistent. Taxes are positively associated with ETHNIC in cities (although the magnitude of the tax increase with ETHNIC is less than half of the spending increase with ETHNIC). Taxes are negatively associated with ETHNIC in metro areas and counties (although the negative association is only significant in the bivariate relationship).

The strong results on fiscal aggregates are on deficits or debt, and total spending. These results suggest the following summary pattern. Total spending tends to go up with higher ETHNIC. Yet

32. Note that in this regression we are controlling for income per capita, so the fact that an ethnically fragmented locality may be poorer cannot be a full explanation of this finding. The correlation between ETHNIC and per capita income is -.24 in the city sample, .016 in the metro sample, and -.077 in the county sample. 
local taxes go up much less with ETHNIC, or may even go down. So the higher local spending with higher ETHNIC is financed by a combination of higher debt and deficits, and more intergovernmental transfers.

\section{SENSITIVITy ANALYSIS}

The consistency of the pattern of our results across different levels of aggregation lends us some reassurance that the results are not badly contaminated by endogenous migration, even if our use of instrumental variables did not fully resolve such endogeneity. A remaining concern about our results is that they could reflect some unobserved third factor that affects both public goods and ethnic divisions. We addressed this in two ways. First, we managed to obtain data for 1960 for some of our variables in order to do panel estimation controlling for unobserved heterogeneity. These results have a number of problems that we describe below. Second, we tried plausible omitted variables in the cross-section estimation, such as percent black, crime, population density, Democratic share of vote for President, and state dummies.

\section{A. Unobserved Heterogeneity with Panel Data}

We concentrated on obtaining data for 1960 , since we wanted a long enough time period that could allow some intertemporal variation in the variables. In fact, the time variation in ETHNIC is very small. Even between 1960 and 1990 the absolute median change in this variable was 0.04 . Hence, we did not even try to obtain data for 1970 and 1980.

We faced several problems in using the 1960 city and county data (metro data were unavailable for 1960). First, jurisdictions change boundaries over time, and so we need to check that the unit of analysis (city, county, etc.) remains relatively unchanged from 1960 to 1990 . We investigated this issue using data on land area of cities and counties. We found that county land areas remain largely constant, while city land areas have risen substantially from 1960 to 1990 , and at an uneven rate across cities. A regression of 1990 area on 1960 area yielded an $R^{2}$ of .99 for counties and only .32 for cities. For this reason, we decided to use only the county data in our panel exercise.

Second, we faced the problem that the 1960 data only identified three ethnic groups: white, black, and other. We redid our 1990 ETHNIC calculation using the same three-way classifica- 
tion and used this for our panel exercise. We also were forced to use attainment of high-school degree rather than of a BA degree because the latter was unavailable in the 1960 sample.

For all of these reasons, the results with panel data should be taken only as suggestive at best.

Table VI shows the panel results for our core variables: the share of education spending, the share of roads spending, and road spending per capita. Although ETHNIC loses significance under fixed effects with a full set of controls, the share variables display a significant and negative bivariate association with ETHNIC using fixed effects. We note, by the way, that the same occurs to most of the other controls, namely in the regressions with a full set of controls most of them are insignificant. ETHNIC remains significant with several combinations of controls, but loses it when income per capita and high school graduates are

TABLE VI

Results from County Data Set for Coefficient on ETHNIC in Pooled SAmple 1960, 1990

\begin{tabular}{|c|c|c|c|c|}
\hline & \multicolumn{4}{|c|}{ Education share of spending } \\
\hline & \multicolumn{2}{|c|}{ Fixed effects } & \multicolumn{2}{|c|}{ Random effects } \\
\hline & No control & All controls & No control & All controls \\
\hline \multirow{5}{*}{$\begin{array}{l}\text { coefficient on ethnic } \\
t \text {-statistic }\end{array}$} & -0.115 & 0.002 & -0.079 & -0.036 \\
\hline & -4.20 & 0.09 & -5.45 & -2.46 \\
\hline & \multicolumn{4}{|c|}{ Roads share of spending } \\
\hline & \multicolumn{2}{|c|}{ Fixed effects } & \multicolumn{2}{|c|}{ Random effects } \\
\hline & No control & All controls & No control & All controls \\
\hline \multirow{5}{*}{$\begin{array}{l}\text { coefficient on ethnic } \\
t \text {-statistic }\end{array}$} & -0.193 & -0.008 & -0.101 & -0.083 \\
\hline & -10.88 & -0.64 & -15.46 & -12.95 \\
\hline & \multicolumn{4}{|c|}{ Roads spending per capita (1990 dollars) } \\
\hline & \multicolumn{2}{|c|}{ Fixed effects } & \multicolumn{2}{|c|}{ Random effects } \\
\hline & No control & All controls & No control & All controls \\
\hline coefficient on ethnic & 28.9 & -5.3 & -77.2 & -79.1 \\
\hline$t$-statistic & 2.27 & -0.39 & -9.60 & -9.56 \\
\hline
\end{tabular}

Random effects results put in italics indicates that the Hausman test rejected orthogonality of the random effects and the regressors. 
introduced. For the road share variable the bivariate coefficient on ETHNIC under fixed effects is more than twice as large as the bivariate coefficient in the county cross section in Table IV. The coefficient on ETHNIC in the bivariate fixed effects regression for education share is about the same as in the corresponding regression in Table IV. The result on roads spending per capita is positive and significant in the bivariate association under fixed effects, and insignificant with the full set of controls. Using random effects, all three variables are negatively and significantly related to ETHNIC both with and without the full set of controls.

Which set of results should we take more seriously? On the one hand, the fixed effects estimator has the virtue that it does not require the country effects to be orthogonal to the right-hand-side variables. A Hausman test indeed rejects orthogonality for five of the six random effects regressions in Table VI. On the other hand, the fixed effects estimator is very costly in degrees of freedom in a sample with a large cross section but only two time periods. We do not think that the strong cross-section results should be disregarded because of the insignificance of ETHNIC in the fixed effects regression with all controls. Given the data problems discussed above, we take some comfort from the surprisingly supportive results from the bivariate fixed effects regression.

\section{B. Cross-Sectional Results}

We think a more promising approach is to directly test the effect on the ETHNIC coefficient of including plausible variables that were omitted in the regressions for Table IV. The results of our sensitivity analysis for our core dependent variables-shares of spending on roads, public education and trash pickup-are presented in Table VII. The entries in the table report coefficients on the ETHNIC variable in different specifications we tried (each coefficient corresponds to one regression). The first row reports the baseline coefficients on ETHNIC from the regressions in Table IV. Each of the subsequent rows reports the results on the ETHNIC variable when we control for additional variables or split the sample in different ways. We organize our discussion below by the type of robustness checks we undertake.

The first issue we look at is the individual components of the ETHNIC variable. The largest minority in American localities is, of course, blacks. Not surprisingly the share of blacks (BLACK) is 
TABLE VII

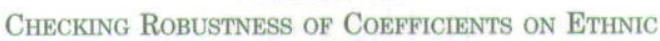
to Possible OMITTED VARIABLES

\begin{tabular}{|c|c|c|c|c|c|c|c|}
\hline \multirow{2}{*}{\multicolumn{2}{|c|}{ Specification }} & \multicolumn{2}{|c|}{ City sample } & \multicolumn{2}{|c|}{ Metro sample } & \multicolumn{2}{|c|}{ County sample } \\
\hline & & $\begin{array}{l}\text { Road } \\
\text { share }\end{array}$ & $\begin{array}{l}\text { Sewerage } \\
\text { share }\end{array}$ & $\begin{array}{l}\text { Road } \\
\text { share }\end{array}$ & $\begin{array}{l}\text { Education } \\
\text { share }\end{array}$ & $\begin{array}{l}\text { Road } \\
\text { share }\end{array}$ & $\begin{array}{l}\text { Education } \\
\text { share }\end{array}$ \\
\hline \multirow{2}{*}{\multicolumn{2}{|c|}{1 Baseline }} & -0.082 & -0.078 & -0.058 & -0.174 & -0.055 & -0.103 \\
\hline & & & -4.395 & -4.835 & & -9.264 & \\
\hline \multirow{2}{*}{2} & $\%$ BLACK and & -0.080 & -0.135 & -0.070 & -0.194 & -0.031 & -0.051 \\
\hline & $\begin{array}{l}\text { \%BLACK- } \\
\text { squared }\end{array}$ & -5.273 & -5.966 & -4.984 & -3.111 & -3.836 & $\begin{array}{c}-1.259 \\
\text { (p-value }=0.2\end{array}$ \\
\hline \multirow[t]{2}{*}{3} & Top quintile by & -0.121 & -0.119 & -0.033 & -0.218 & -0.025 & -0.278 \\
\hline & population & -4.048 & -2.9 & -1.86 & -1.700 & -2.489 & -5.853 \\
\hline \multirow[t]{2}{*}{4} & All but top quin- & -0.077 & -0.071 & -0.059 & -0.174 & -0.063 & -0.074 \\
\hline & tile & -5.549 & -3.636 & -4.456 & -3.347 & -9.328 & -2.670 \\
\hline \multirow[t]{2}{*}{5} & Population den- & -0.074 & -0.070 & -0.056 & -0.171 & -0.055 & -0.102 \\
\hline & sity & -5.847 & -3.888 & -4.634 & -3.565 & -9.292 & -4.117 \\
\hline \multirow{4}{*}{7} & Violent crime & -0.079 & -0.081 & -0.064 & -0.130 & -0.050 & -0.049 \\
\hline & per capita & -5.200 & -3.912 & -4.198 & -2.043 & -6.672 & -1.706 \\
\hline & Democratic & & & -0.061 & -0.167 & -0.054 & -0.097 \\
\hline & $\begin{array}{l}\text { share of vote for } \\
\text { President }\end{array}$ & N/A & N/A & -4.827 & -3.287 & -8.616 & -3.775 \\
\hline \multirow[t]{2}{*}{8} & State dummies & -0.064 & -0.080 & -0.044 & -0.087 & -0.028 & -0.118 \\
\hline & & -4.382 & -3.453 & -3.429 & & -4.439 & -4.161 \\
\hline
\end{tabular}

Heteroskedasticity-consistent $t$-statistics are reported below coefficient estimates.

correlated quite strongly with ETHNIC. ${ }^{33}$ Therefore, one may wonder whether ETHNIC is practically equivalent to BLACK, which may imply different interpretations of our results presented thus far. The difference between the two variables lies in: (1) ETHNIC captures divisions between five ethnic groups while BLACK captures only black versus nonblack; (2) ETHNIC treats as equivalent two observations (a) 70 percent whites and 30 percent blacks and (b) 30 percent whites and 70 percent blacks, whereas BLACK implies the two are very different. If, for whatever reason, BLACK was the "true" variable affecting local fiscal behavior, then the coefficients on ETHNIC should go to zero when BLACK is included in the regressions. The second row of Table VII in which we control for BLACK and BLACK-squared shows that this is not the case. Results for the road-share

33. The correlation coefficient for the city, metro, and county samples are 0.58 , 0.72 , and 0.80 , respectively. 
dependent variable are about the same as in the baseline case and statistically significant at conventional levels for all three samples. The magnitude of the relationship between ethnic heterogeneity and share of spending on roads becomes slightly stronger in the metro sample and slightly weaker in the county sample (compared with baseline coefficients). ${ }^{34}$ Results for education share do not change significantly in the metro sample, but become weaker in the county sample: the magnitude of the point estimate drops to about half of its value in the baseline case, and the associated standard error increases from 0.025 to 0.041 ( $p$-value $=0.20$ ). However, neither BLACK nor BLACK-squared is significant in any of the education share regressions. Because of the fairly high correlation between ETHNIC and BLACK in the county sample $(0.80)$, the reduction in the $t$-statistic on the ETHNIC variable is likely due to multicollinearity. ${ }^{35} \mathrm{On}$ the other hand, the results for sewerage spending become stronger with the additional controls of BLACK and BLACK-squared ${ }^{36}$ Overall, we do not find a systematic effect of BLACK for our results, and the continued strong results on ETHNIC indicate that it is not just proxying for BLACK in its effect on public goods provision.

Another closely related question: do our results on ETHNIC come about because government fiscal outcomes are different depending on whether whites or blacks are in charge (i.e., whether the median voter is black or white)? The travails of black majority cities such as Washington, DC, are well-known. Moreover, it is true that black majority cities have much higher ETHNIC (.46) than do white majority cities (.27), because white majorities are usually larger than black majorities. So ETHNIC could just be proxying for black majorities versus white majorities.

This turns out not to be true. We test the idea by restricting the sample to localities with a white majority. If the effect of ETHNIC on our fiscal policy variable was due to the difference

34. Estimated coefficients on BLACK and BLACK-squared are not significant in the city or metro samples. For the county sample the estimated coefficients (with $t$-statistics in parentheses) on BLACK and BLACK-squared, respectively, are as follows: $-0.093(-4.51)$ and $0.162(4.021)$. The implied turning point in the quadratic is BLACK $=0.29$.

35. The reduction in the magnitude of the coefficient indicates that majorities' reaction to increasing minority share (by reducing expenditure on public education) is somewhat weaker when the minority that is increasing in population share is nonblack. There is, however, only weak evidence for this since this is not true in the metro sample and is also not true for other types of productive good spending.

36. The estimated coefficients (with $t$-statistics in parentheses) on BLACK and BLACK-squared, respectively, are as follows: $0.237(3.67)$ and $-0.314(-3.24)$. The implied turning point in the quadratic is BLACK $=0.36$. 
between black-majority and white-majority cities, then the coefficients on ETHNIC should go toward zero in the solely whitemajority sample. In fact, when we rerun all our regressions on the sample of localities with a white majority, our results are almost entirely unchanged. This result is unsurprising since the vast majority of the sample consists of white-majority localities (92 percent in cities, 100 percent in metro areas, and 98 percent in counties). Thus, our results are consistent with the idea that white majorities vote to reduce the supply of productive public goods as the share of blacks and other minorities increases..$^{37}$

The next issue we look at for checking the sensitivity of our results is the effect of population size and concentration. Although we controlled for log of the city population in the base regressions, we now split the sample by population size to check for potential nonlinear effects. Since the public goods problems of big urban areas are well-known, we address the concern that the nature of the relationship between ethnic heterogeneity and public goods may be different in big versus small cities. In particular, we see whether the results are being driven by the worst outcomes in big cities versus the rest of the sample. The third row of Table VII shows the results on ETHNIC when we restrict the sample to the top quintile of observations by population. The next row shows the results for the complement sample to the above. All regressions have log of the city population as one of the controls. If our results presented earlier were simply masking the difference between big and small urban areas, the findings on ETHNIC would disappear when we look at them separately. The reported coefficients in the second and third rows of Table VII show that this is not the case. ETHNIC is significant at 5 percent in all specifications except for the top-quintile metro regressions in which it is significant at 10 percent. The top-quintile metro sample has only 61 observations. Looking at changes in the magnitude of the coefficients on ETHNIC, the biggest changes are for the top-quintile regressionsbig cities, counties, and metro areas seem slightly different. However, it is difficult to see a systematic pattern in this "differ-

37. A serious statistical analysis of localities with a black majority is almost impossible. The samples are too small. In the city or county sample, there are between 21 and 40 observations (14-33 degrees of freedom). There are no black majority metropolitan areas. In the black majority cities, ETHNIC will increase as the share of blacks decreases and as the share of whites increases (a check of the sample shows that the variation in ETHNIC in the black majority cities is driven mainly by black versus white). In the black majority city sample with 36 observations, just for the record, the only statistically significant result is that the share of police spending still goes up with ETHNIC. 
ence" except for the education-share regressions. The impact of ethnic heterogeneity on education spending is considerably greater in big urban areas for both the metro and county samples. For roads the effect is bigger in magnitude in big cities but smaller in big metro areas and counties. We conclude that the relationship between ethnic heterogeneity and public goods spending is robust to both big and small cities and that for education the problem may be exacerbated in big urban areas. Related to the issue of big urban areas, we look at population density as a possible omitted variable driving the results. Row 5 in Table VII presents the results. Controlling for population density leaves the coefficients on ETHNIC virtually unchanged from their baseline values.

Another possible omission from our right-hand-side variables is the crime rate in cities. Cities with higher crime rates may be associated with greater ethnic heterogeneity and smaller spending shares on roads, education, and sewerage (because of greater spending on police for instance). Indeed, in our sample crime is positively correlated with ethnic heterogeneity and negatively with spending shares on education, roads, and sewage. In row 5 we add violent crime per capita as one of the control variables. ${ }^{38}$ Results on ETHNIC do not change significantly except for education-share in the county sample in which the coefficient reduces to about half of its value in the baseline case (the standard error does not change much: 0.025 versus 0.028 ). Although the coefficient is significant at the 10 percent level of confidence, the reduction indicates that part of the effect may be going through the variation in crime rates.

We next consider the Democratic share of the vote for President as a possible omitted variable. Cities with greater shares of minorities may be Democrat cities or counties, which may affect their fiscal decisions. The sixth row in Table VII shows that controlling for this for the metro and county samples does not alter our findings on ETHNIC. ${ }^{39}$

Our final concern is heterogeneity across states. States could vary in their institutional arrangements for provision of public services. The last row in Table VII shows the results on ETHNIC with a complete set of state dummy variables. There is a slight reduction in the coefficients for road-share regressions, with the most pronounced effect in the county sample. ETHNIC is signifi-

38. Violent crime, as defined by the Census Bureau, includes murder, forcible rape, robbery, and aggravated assault.

39. We do not have these voting data for the city sample. 
cant at conventional levels in all three samples. For sewerage spending the coefficient on ETHNIC remains virtually unchanged from its baseline value. For the education share there is a reduction in magnitude of the point estimate for the metro sample but not for the county sample. In the metro sample ETHNIC is on the cutoff point for significance at the 10 percent level, and in the county sample it is significant at the 1 percent level. Overall, the results on ETHNIC seem robust to controlling for state-specific effects.

To summarize, the results of our sensitivity analysis indicate that the described empirical relationship between ethnic heterogeneity and spending on core public goods is robust to controlling for a broad array of possible omitted variables. While the estimated coefficient on ETHNIC changes somewhat depending upon the specification, in most cases the estimated coefficient lies within the 95 percent confidence interval associated with the baseline estimate.

\section{Conclusions}

More ethnically diverse jurisdictions in the United States have higher spending and higher deficits/debt per capita, and yet devote lower shares of spending to core public goods like education and roads. The higher spending in more ethnically diverse jurisdictions is financed in part by higher intergovernmental transfers rather than by local taxes. This pattern is broadly consistent with political economy theories in which heterogeneous and polarized societies will value public goods less, patronage more, and will be collectively careless about fiscal discipline.

These results point to some interesting future research questions. The issue of ethnic fragmentation is obviously related to the problem of racial segregation, since ethnically fragmented jurisdictions are often segregated. An important question that we want to pursue in further research is how the negative effects of ethnic fragmentation on public goods relate to segregation. First of all, as we mentioned above, if ethnic fragmentation with segregation leads to a low supply of public goods (particularly education), then the segregated disadvantaged ethnic group may fall farther behind, perpetuating a vicious cycle. Note that public school is not the only example of this. Wilson [1996], for instance, 
notes that poor public transportation systems from inner city ghettos to the location of job opportunities increase the costs of finding and keeping jobs for inner city minorities. In Washington, DC, by way of anecdote, the segments of the metro that served poor black neighborhoods were the last (by many years) to be completed-some are still not completed today.

Second, since ethnic fragmentation is associated with public goods problems documented in the present paper, policy-makers may be tempted to choose segregation and decentralization in order to enforce relatively homogeneous communities. Bénabou [1996b] presents a model in this spirit, where stratification by income is more efficient in the short run to deal with heterogeneity in the production process. However, there is a second dynamic effect: stratification increases heterogeneity and therefore, in the long run decreases economic efficiency. We think there are analogous questions to be pursued for stratification by ethnic group. While separation of ethnic groups may have some short-term benefits, it may have devastating long-run costs. ${ }^{40}$

In summary, our results contribute to explaining why the problem of urban public goods in America appears so difficult. The public goods problem is linked to another problem that also appears almost insurmountable: ethnic divisions.

\section{APPENDIX: DESCRIPTION OF THE DATA}

Definitions of variables are the same in all data sets so details on variables are given in the city section and not repeated in the metro and county sections.

\section{City Data}

The city data are all downloaded electronically from the CD-ROM version of the 1994 County and City Databook (CCD), published by the Bureau of the Census.

40. Segregation has decreased in the last twenty years, as noted by Cutler, Glaeser, and Vigdor [1996]. It would be interesting to investigate what effect this has had on urban public goods. One currently popular story worth testing is that the most successful blacks are moving to the suburbs; those left in the inner city neighborhoods are perceived as more and more different from the white majority living in white neighborhoods; the ethnic polarization and the public goods problems get even worse. 
Our most comprehensive city sample consists of 1083 observations. It includes the 1070 incorporated places of population 25,000 or more counted in the 1990 Census, 8 Census Designated Areas of Hawaii (since Hawaii has no incorporated places recognized by the Bureau of the Census) and the five boroughs of New York City. ${ }^{41}$ For consistency we treat New York City as one entity and do not use the observations on the five boroughs since for some of our measures the data are not provided on a breakdown by borough basis.

We checked the data for anomalous values by sorting each variable and examining the extreme high and low observations. This procedure led us to exclude two anomalous observations: Streamwood, IL, which has 0 for local government expenditure, and Superior, WI, which has 0 for local government taxes. We discuss the handling of other data anomalies below.

\section{City government spending}

The CCD data on city government spending are collected from the 1992 Census of Governments. Expenditure includes capital outlay and interest on debt.

As described in the Government Finance and Employment Classification Manual, June 1992, expenditure includes anything executed in the city budget, regardless of whether it is partly or wholly financed by a higher level of government.

Expenditure categories given in the County and City Databook are Education, Health and Hospitals, Police Protection, Fire Protection, Public Welfare, Highways, and Sewerage and Solid Waste Management. These categories are not exhaustive, as noted in the text of the paper.

Education includes local government-operated elementary and secondary schools, and any universities, colleges, junior, or community colleges operated by the local government.

Health and Hospitals includes treatment and immunization clinics, environmental health services, ambulance services, support for private hospitals, and construction, maintenance and operation of public hospitals.

Police includes patrols, communications, custody of persons awaiting trial, and vehicular inspection.

41. In all our regressions we exclude two cities that have unexplained zeros for some variables on the CD ROM, as explained next: Streamwood, IL, and Superior, WI. 
Waste Management includes sanitary and storm sewers, sewage disposal, street cleaning, pickup, and disposal of garbage.

Some functions are usually executed by other levels of government and so appear with zero spending in many cities. Education spending, for example, has 866 zeros out of 1020 observations (the New England states and Virginia account for almost all of positive education spending by cities). Education is usually executed by counties or special school districts, and so does not pass through the city budget. Likewise, health and hospitals has 306 zeros out of 1020 , and welfare has 750 zeros out of 1020 . We did not run regressions for expenditure variables with a majority of zeros.

Even spending on seemingly unavoidable city government functions is sometimes not assigned to cities. To take a random example, Bowie, MD, a suburb of Washington, DC, shows zero spending on police. Bowie does not have its own city police force; crime victims in Bowie summon the Prince George's County police instead. (This problem is not that serious for police spending: there is only one other zero police observation in the sample.) Fire and waste management also have some zeros (65 and 77, respectively, out of 1020 observations).

The (hopefully random) way in which different kinds of expenditures are assigned or not assigned to different levels in different cities will introduce some noise into the other public spending share dependent variables. As we discuss in the text, we use data sets at different levels of aggregation in part to make sure that the results do not depend on arbitrary expenditure assignment between levels.

The electronic data for expenditure and taxes per capita on the CD ROM did not match the printed version in the CCD, and included some absurdly high values. When we recalculated the per capita figures from aggregate spending and population data, the calculated values came close to reproducing the printed values in the $\mathrm{CCD}$ and stayed within a plausible range.

Intergovernmental revenue per capita includes amounts received from other governments as fiscal aid in the form of shared revenues and grants-in-aid, as reimbursements for performance of general government activities and for specific services for paying government (e.g., care of prisoners or contractual research) or in lieu of taxes. Excludes amounts received from other governments for sale of property, commodities, and utility services. 


\section{Ethnic classification data}

1990 Census data are reported according to how people identify themselves on a list that includes Black, American Indian, Asian, White, and Other. Hispanic is not a mutually exclusive category with the other ethnic classifications, since Hispanics can be of any race. Other in the above list seems to proxy for Hispanic, as the two have a correlation of 0.91 .

\section{Educational attainment}

Educational attainment (BAGRAD) is from a sample of persons 25 years and over and is carried out in the 1990 census.

\section{Income data}

Data on income in 1989 were collected during the 1990 census from a sample of persons fifteen years old and over. Money income includes wage or salary income, self-employment income, interest dividends, social security benefits, welfare income, and retirement income. The definition of Household is all persons who occupy a housing unit, defined as a house, apartment, mobile home, or a single room occupied as separate living quarters.

\section{Metro Areas}

The metro data are downloaded from the $1994 \mathrm{CD}$ ROMs called the City and County Compendium (CCC) and City and County Plus (CCP), which are an expanded electronic version of the publication City and County Extra, by Slater Hall Information Products.

The metro sample includes all Metropolitan Statistical Areas (MSAs) and Primary Metropolitan Statistical Areas (PMSAs) from the City and County Extra of Slater Hall Information Products, Inc. The minimum size for metropolitan area is 50,000. The metro data aggregate all levels of local government in the metro area, including county, school district, other local district, and city.

PMSAs are MSAs that form part of a larger Consolidated Metropolitan Statistical Area (CMSA). Baltimore and Washington PMSAs together make up the Baltimore-Washington CMSA, for 
example. We decided that PMSAs are likely to be closer than CMSAs to the concept of regional political economy that we wished to capture.

The definition of MSA includes a generous definition of the urban hinterland. The Washington DC PMSA, for example, includes Montgomery, Prince George's, Frederick, Charles, and Calvert Counties in Maryland; Alexandria, Arlington, Fairfax, Loudon, Prince William, Stafford, Clarke, Warren, Fauquier, Culpeper, Spotsylvania, and King George Counties in Virginia; and Berkeley and Jefferson Counties in West Virginia. This makes the metro data in general more aggregated than the county data.

We checked the data for anomalous observations by sorting each variable and examining the high and low values. This procedure leads us to exclude Honolulu, which strangely has a zero value for education spending, and New York City, which has extreme values for expenditure and taxes per capita (3.5 and 3.3 times larger than the second largest observations, respectively). Although many might believe that taxes and spending are extreme in the Big Apple, we found that the population base implicit in this extreme figure in the data diverged from the reported population by a factor of 3 .

We excluded the local debt per capita observation for RICHLAND-KENNEWICK-PASCO, WA (MSA), because it is larger by a factor of 4 than the second largest observation. We have the vague memory that there is a public utility nuclear plant boondoggle going on here, but we have not checked it out further.

The expenditure share data include classification for spending in the following categories: education, health and hospitals, police, welfare, and roads. The only one of these categories with some zero observations was welfare ( 18 zeros out of 307 observations). As in the other data sets, these categories are not exhaustive.

\section{County Data}

The county data are also downloaded from the $1994 \mathrm{CD}$ ROMs called the City and County Compendium (CCC) and City and County Plus (CCP) by Slater Hall Information Products. The county data aggregate all levels of government located in the county - city, school district, county, and any other.

These data cover the full 3140 counties in the United States. Some of the counties are thinly populated-the minimum in the 
sample for population in 1990 is 52. As explained in the text, we decided to focus on "urban" counties because of our focus on urban public goods. We therefore chose counties with populations above 25,000 , the same population minimum the CCD uses for cities. This reduced the sample to 1462 counties.

As with the other data sets, we checked for anomalies by sorting each variable and examining extreme values. We noticed systematic problems with sample observations in Virginia-many have zero spending on core local government functions like roads and education.

Further investigation revealed that Virginia (alone among the 50 states) has independent cities listed separately, which messes up data reporting. For example, both Fairfax City and Fairfax County are listed with their own data for all concepts. If, for example, the Fairfax County road authority handles the roads for both city and county, and the Fairfax city school board handles the education for both city and county, then there will be a zero entry for road spending in Fairfax city and for education spending in Fairfax county. Not knowing how to resolve this problem, we wound up omitting all data for Virginia.

Counties in Hawaii were anomalously zero or near zero for education spending, just as Honolulu's education spending was strangely zero in the metro data. We omitted counties in Hawaii from the data set.

The other data anomaly that we noticed and corrected was that federal expenditure per capita was listed as zero for four counties in New York City-New York County itself, the Bronx, Queens, and Richmond. This would imply that there were no federal judges or welfare recipients in New York City, which contradicts conventional wisdom. A check of the published source revealed that these data were not reported because of a problem of assigning expenditure between these counties within New York City. We substituted NAs for the zeros.

The county data, like the metro data, include classification for spending in the following categories: education, health and hospitals, police, welfare, and roads. In the sample that we used, two of these categories still showed some zero entries, probably reflecting assignment of these functions to higher levels of government. There were 207 zeros out of a sample of 1386 observations in welfare and 13 zeros out of 1386 for health and hospitals. 


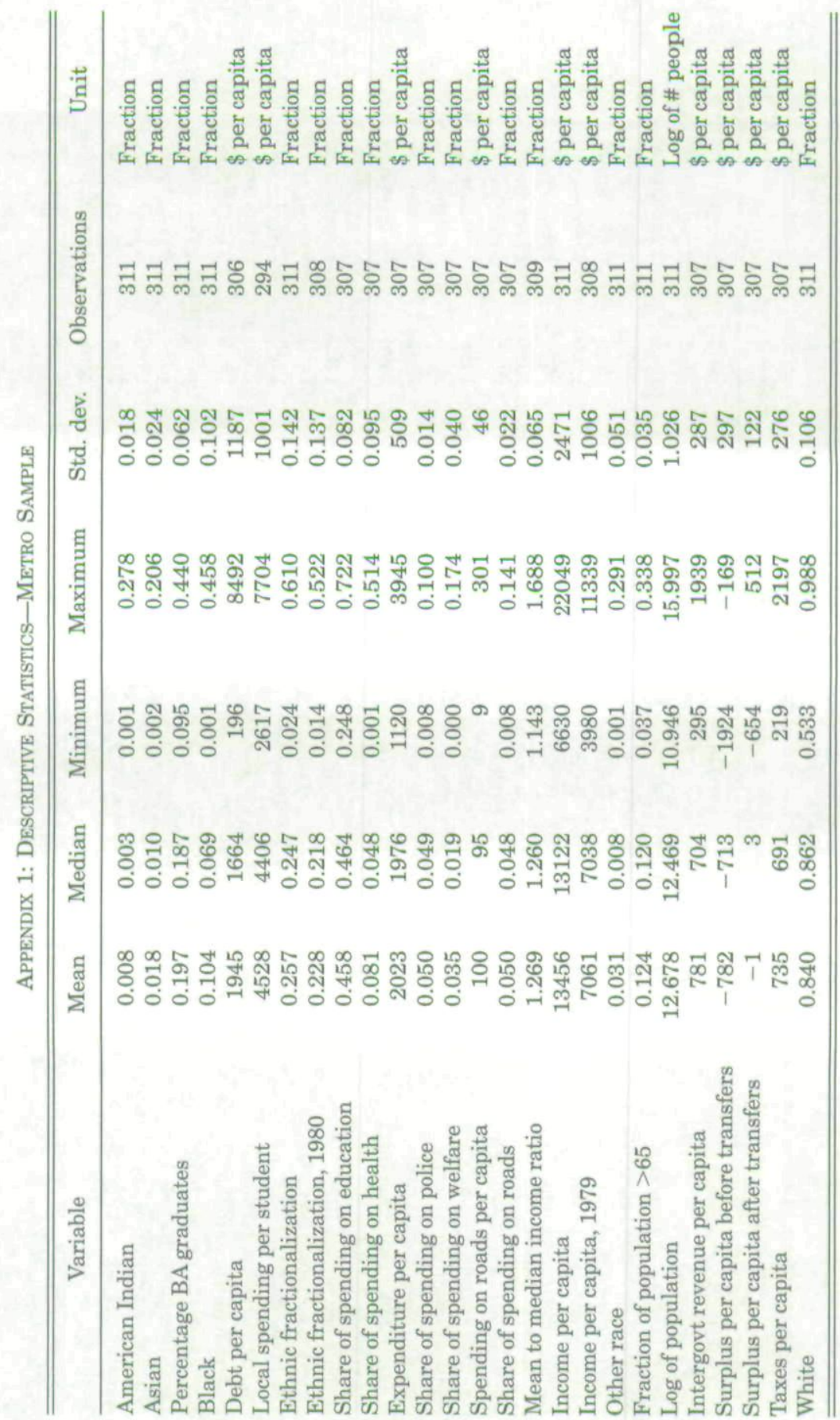




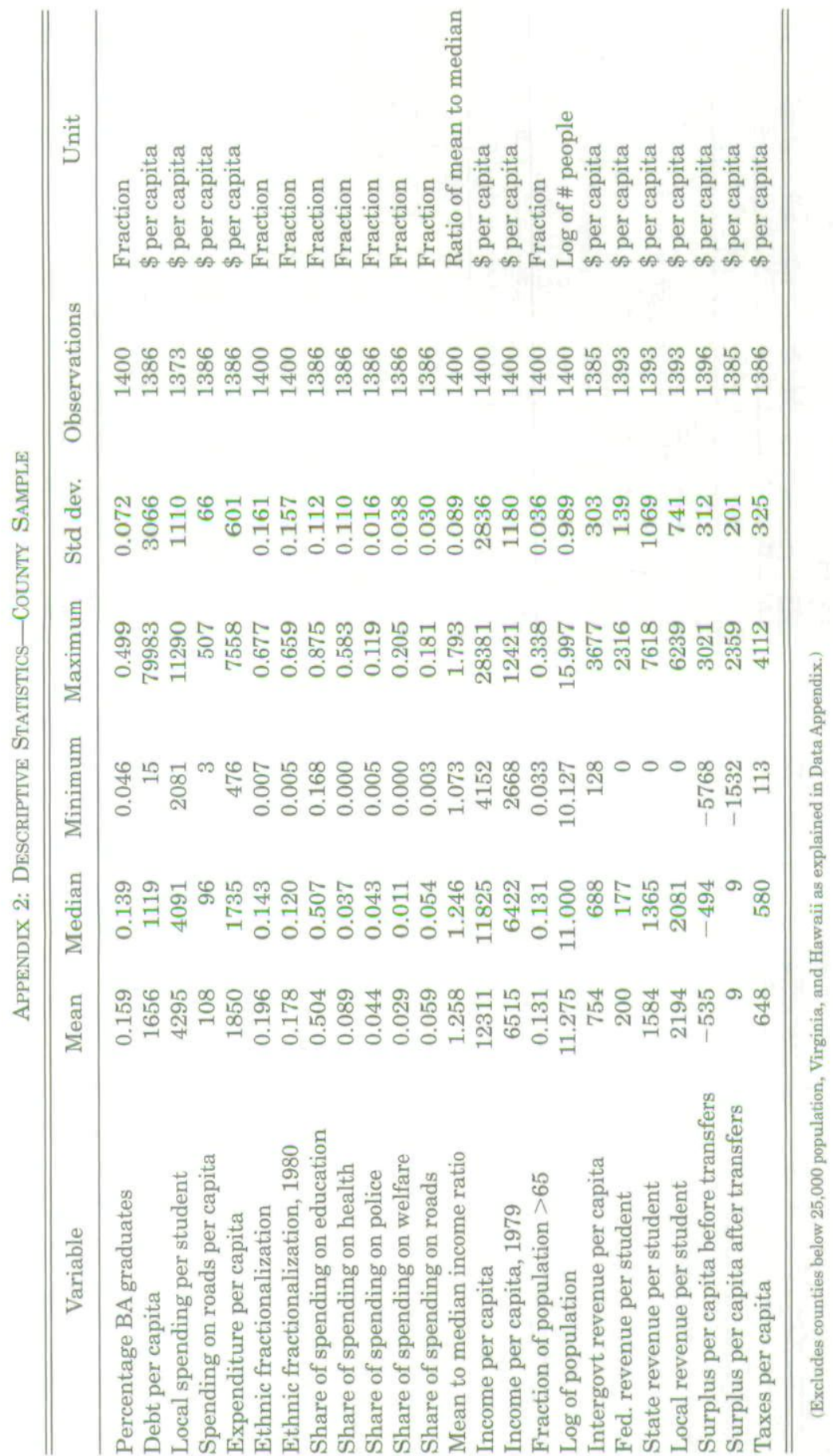


Harvard University, Massachusetts Institute of Technology, National Bureau OF ECONOMIC RESEARCH, AND CEPR

UNIVERSITY OF CALIFORNIA AT BERKELEY

WORLD BANK

\section{REFERENCES}

Alesina, A., R. Baqir, and W. Easterly, "Redistributive Public Employment,"NBER Working Paper No. 6746, 1997.

Alesina, A., and A. Drazen, "Why Are Stabilizations Delayed?" American Economic Review, LXXX (1991), 1170-1188.

Alesina, A., and R. Perotti, "Fiscal Expansions and Fiscal Adjustments in OECD Countries," Economic Policy, XXI (1995), 205-248.

Alesina, A., and R. Perotti, "Budget Deficits and Budget Institutions," in Fiscal Institutions and Fiscal Performance, J. Poterba and J. von Hagen, eds. (Chicago: University of Chicago Press, 1999), pp. 13-36.

Alesina, A., and E. Spolaore, "On the Number and Size of Nations," Quarterly Journal of Economics, CXII (1997), 1027-1056.

Alt, J., and R. Lowry, "Divided Government and Budget Deficits: Evidence from the States," American Political Science Review, LXXXVII (1994), 811-828.

Atkinson, A. B., and J. Stiglitz, Lectures on Public Economics (New York: McGraw-Hill, 1980).

Bell, Derrick, Faces at the Bottom of the Well: The Permanence of Racism (New York: Basic Books, 1992).

Bénabou, R., "Equity and Efficiency in Human Capital Investment: The Local Connection," Review of Economic Studies, LXIII (1996a) 237-264.

, "Heterogeneity, Stratification, and Growth: Macroeconomic Implications of Community Structure and School Finance," American Economic Review, LXXXVI (1996b), 584-609.

"Workings of a City: Location, Education, and Production," Quarterly Journal of Economics, CVIII, (1993), 619-652.

Borjas, G., "Ethnicity, Neighborhoods, and Human Capital Externalities," American Economic Review, LXXXV (1995), 365-390.

Canning, D., and M. Fay, "The Contribution of Infrastructures to Economic Growth," unpublished, 1993.

Cutler, D., D. Elmendorf, and R. Zeckhauser, "Demographic Characteristics and the Public Bundle," Public Finance, XLVIII (1993), 178-198.

Cutler, D., and E. Glaeser, "Are Ghettos Good or Bad?" NBER Working Paper No. $5163,1995$.

Cutler, D., E. Glaeser, and J. Vigdor, "The Rise and Decline of the American Ghetto." unpublished, 1996.

Durlauf, S., "A Theory of Persistent Income Inequality," Journal of Economic Growth, I (1996), 75-93.

Easterly, W., and R. Levine, "Africa's Growth Tragedy: Policies and Ethnic Divisions," Quarterly Journal of Economics, CXII (1997), 1203-1250.

Epple, D., and T. Romer, "Mobility and Redistribution," Journal of Political Economy, XCIX (1991), 828-858.

Glaeser, E., J. Scheinkman, and A. Shleifer, "Economic Growth in a Cross-Section of Cities," Journal of Monetary Economics, XXXVI (1995), 117-143.

Goldin, C., and L. Katz, "Human Capital and Social Capital: The Rise of Secondary Schooling in America, 1910 to 1940," NBER Working Paper No. 6439, 1998.

Hacker, Andrew, Two Nations: Black and White, Separate, Hostile and Unequal (New York: Scribner's, 1995).

Huckfeldt, R., and C. W. Kohfeld, Race and the Decline of Class in American Politics (Urbana: University of Illinois Press, 1989).

Kontopoulos, Y., and R. Perotti, "Fragmented Fiscal Policy," unpublished, 1997.

Kozol, J., Savage Inequalities: Children in America's Schools (New York: Crown Publishers Inc., 1991).

Lieberman, M., Public Education: An Autopsy (Cambridge, MA: Harvard University Press, 1993). 
Luttmer, Erzo F. P., "Group Loyalty and the Taste for Redistribution," unpublished, 1997.

Mauro, P.,"Corruption and Growth," Quarterly Journal of Economics, CX (1995), $681-712$

Meltzer, A., and S. Richards, "A Rational Theory of the Size of Government," Journal of Political Economy, LXXXIX (1981), 314-327.

Page, C., Showing My Color: Impolite Essays on Race and Identity (HarperCollins, 1996).

Poterba, J., "State Responses to Fiscal Crises: The Effects of Budget Institutions and Politics," Journal of Political Economy, CII (1994), 799-884.

"Demographic Structure and the Political Economy of Public Education," NBER Working Paper No. 5677, July 1998.

Roubini, N., and J. Sachs, "Government Spending and Budget Deficits in the Industrialized Countries," Economic Policy, VIII (1989), 99-132.

Rubinfeld, D., "The Economics of the Local Public Sector," in A. J. Auerbach and M. Feldstein, eds., Handbook of Public Economics, II (Amsterdam: NorthHolland, 1987), pp. 571-645.

Rubinfeld, D., P. Shapiro, and J. Roberts, "Tiebout Bias and the Demand for Local Public Schooling," Review of Economics and Statistics, LXIX (1987), 426-437.

Tiebout, C., "A Pure Theory of Local Expenditures," Journal of Political Economy, LXIV (1958), 416-424.

Velasco, Andres, "A Model of Endogenous Fiscal Deficits and Delayed Fiscal Reforms," CV Starr Center Report, 93-94, New York University, 1994.

Weingast, B., K. Shepsle, and C. Johnsen, "The Political Economy of Benefits and Costs: A Neoclassical Approach to Distributive Politics," Journal of Political Economy, LXXXIX, (1981), 642-664.

Wilson, W., The Truly Disadvantaged: The Inner City, the Underclass, and Public Policy (Chicago: University of Chicago Press, 1987).

When Work Disappears: The World of the New Urban Poor (New York: Knopf-distributed by Random House, Inc., 1996). 
Copyright of Quarterly Journal of Economics is the property of MIT Press and its content may not be copied or emailed to multiple sites or posted to a listserv without the copyright holder's express written permission. However, users may print, download, or email articles for individual use. 